\title{
Impacts of Clear Cutting on Diversity of Ground Ants (Hymenoptera: Formicidae) in Pine Plantation Forest in Sukabumi Forest Management Unit, West Java
}

\author{
Ahmad Budiaman ${ }^{1 *}$, Noor Farikhah Haneda ${ }^{2}$, Adhiguna Indra Nugraha ${ }^{3}$, Frama Haikal ${ }^{3}$ \\ ${ }^{1}$ Department of Forest Management, Faculty of Forestry and Environment, IPB University, Academic Ring Road, Campus IPB \\ Dramaga, Bogor, Indonesia 16680 \\ ${ }^{2}$ Department of Silviculture, Faculty of Forestry and Environment, IPB University, Academic Ring Road, Campus IPB \\ Dramaga, Bogor, Indonesia 16680 \\ ${ }^{3}$ Graduate Program of Forest Management Sciences, Faculty of Forestry and Environment, IPB University, \\ Academic Ring Road, Campus IPB Dramaga, Bogor, Indonesia 16680
}

Received June 17, 2020/Accepted March 4, 2021

\begin{abstract}
Clear cutting is the main source of timber production of plantation forest management in Indonesia, but this activity disrupts the lives of ground ants. It is rarely known how clear cutting affects the ground ant community in the Indonesian plantation forest. The study aimed to analyze the impacts of clear cutting on the diversity of ground ants in the pine plantation forest of Sukabumi, West Java. The study compared the community structure of ground ants before clear cutting and after clear cutting. Ground ants were collected using a pitfall trap. Trapping of ground ants was carried out six days before the clear cutting and six days after the clear cutting. The ground ants were identified to the morphospecies level and classified into their functional role. The results showed that clear cutting alters the community indices of ground ants. Abundance, morphospecies composition, diversity index, richness index, and evenness index of ground ants after clear cutting was lower compared with those before clear cutting. The clearfelled area due to clear cutting provided favorable habitat for the generalist groups of ground ants, but negatively affected the predator and forager groups of ground ants. These findings can be used as an important factor in the development of environmenllyt-friendly forest harvesting systems in Indonesian plantation forests.
\end{abstract}

Keywords: biodiversity, clear cutting, environment, ground ants, pine

\section{Introduction}

Plantation forests are the main source of log production in Indonesia. The area of plantation forests in Indonesia is 11.3 million ha, which produced 40.13 million $\mathrm{m}^{3}$ of round wood in 2018 (AIFCH, 2019). The plantation forests have also a strategic role in the Indonesian forestry sector. In 2011, the contribution of the forestry sector to the national gross domestic Brutto of Indonesia reached 2.3\% (CBS, 2013). Around $3.5 \%$ of $\log$ production from plantations forests are produced from plantation forests in the island of Java, which is managed by the state-owned forestry company (Perum Perhutani). Log production of Perum Perhutani was 636,092 $\mathrm{m}^{3}$ in 2017 (MEF, 2019). Six types of forest harvesting systems are applied to the plantation forest management at Perum Perhutani, i.e. clear cutting, retention cutting, clearance cutting, maintenance cutting, unexpected cutting, and thinning. The most common type of forest harvesting system applied at Perum Perhutani is thinning and clear cutting (Perum Perhutani, 2006).

The plantation forests do not only produce timber but also produce non-timber forest products and provide environmental services (Brockerhoff et al., 2013; Warman, 2014). Besides producing valuable timber, the clear cutting caused changes in the forest environment (Paillet et al., 2010; Johansson et al., 2016). One of the environmental impacts due to clear cutting is an alteration in the structure of the forest floor (Česonienè et al., 2018), which disturbed the habitat of forest floor-dwelling species, including ground ants (Andersson et al., 2012; Tausan et al., 2017). The ground ants (Hymenoptera: Formicidae) have many critical roles in maintaining and functioning forest ecosystems (Tausan et al., 2017; Tiede et al., 2017), including maintaining soil fertility and nutrient cycling (Wibowo \& Slamet, 2017; Widhiono et al., 2017; Lessard, 2019). Ants are also widely used to understand the principles of ecology and conservation, as well as environmental monitoring programs (Ribas et al., 2012).

Previous studies showed that clear cutting caused varied impacts on vertebrates (Acuna \& Estades, 2011; Eyre et al., 2015), as well as forest invertebrates (Johansson et al., 2016; Jokela et al., 2019). The clear cutting did not affect the community structure of some ants, but some other ants are significantly affected by the clear cutting (Khaliq et al., 2014; Garcia-Tejero et al., 2018). The distribution and composition of red ants change after the clear cutting of plantation forests (Żmihorski, 2010; Johansson \& Gibb, 
2012).

Even though the ants have an important role in the forest ecosystem, but the ants do not become a priority concern in biodiversity research in Indonesia, especially in the management of plantation forests. Studies on the impact of clear cutting of plantation forests in Indonesia have been carried on soil compaction (Matangaran \& Suwarna, 2012), quality of watershed and sedimentation (Supangat et al., 2016), and logging residue (Budiaman et al., 2014; Andini et al., 2017). Therefore, this study analyzes the impact of clearcutting on the diversity of ground ants in the pine (Pinus merkusii Jungh et de Vriese) plantation forest, and the response of ground ants on habitat change due to clear cutting.

\section{Methods}

The study was conducted in a 9.4 ha of a clear cutting compartment of pine forest plantation in Forest Management Sub-unit of Cikawung, Forest Management Unit of Sukabumi, West Java (S65 $7^{\prime} 00^{\prime \prime}-\mathrm{S} 7^{\circ} 20^{\prime} 00^{\prime \prime}$; $\left.\mathrm{E} 106^{\circ} 41^{\prime} 00^{\prime \prime}-\mathrm{E} 107^{\circ} 00^{\prime} 00^{\prime \prime}\right)$. The pine forest stand was 39 years old. The topography of the study site varied from flat to steep and was at an altitude of $700 \mathrm{~m}$ asl. The study was carried out in April-September 2018. The forest harvesting system used produced short wood assortments. The tree was cut manually using chain saws. Logs' bucking was carried out at the cutting site using chain saws. Logs were manually skidded to the nearest transport road.

A cluster plot for Forest Health Monitoring (FHM) plot was used in this study. The cluster plot consists of four plot units. Each plot unit consists of an annular plot, subplot, and micro plot. Ground ants were sampled in the micro plot (Figure 1). One cluster plot represents 1 ha of the observed study area. The sampling intensity used was $45 \%$ of the observed clear cutting area. Thus the total number of cluster plots was 4 plots. The cluster plots were systematically placed in the clear cutting compartment with a distance between cluster plots of $200 \mathrm{~m}$ (Figure 2). Ground ants were collected using a pitfall trap. Five pitfall traps were installed in a diagonal pattern in the center of each micro plot (Haneda \& Marfuah, 2013). Each cluster plot consisted of 20 pitfall traps. A pitfall trap was set as a sample unit. Thus the total sample unit for insect sampling was 80 units. The installation of the pitfall trap was carried six days before the clear cutting and six days after the clear cutting. Harvesting of trapped ground ants was done 48 hours after setting the pitfall trap. The ground ants were identified to the morphospecies level using the key of Bolton (1994) and Borror et al. (1996) and classified to their functional role using the classification of Andersen (2000), and Haneda \& Yuniar (2020).

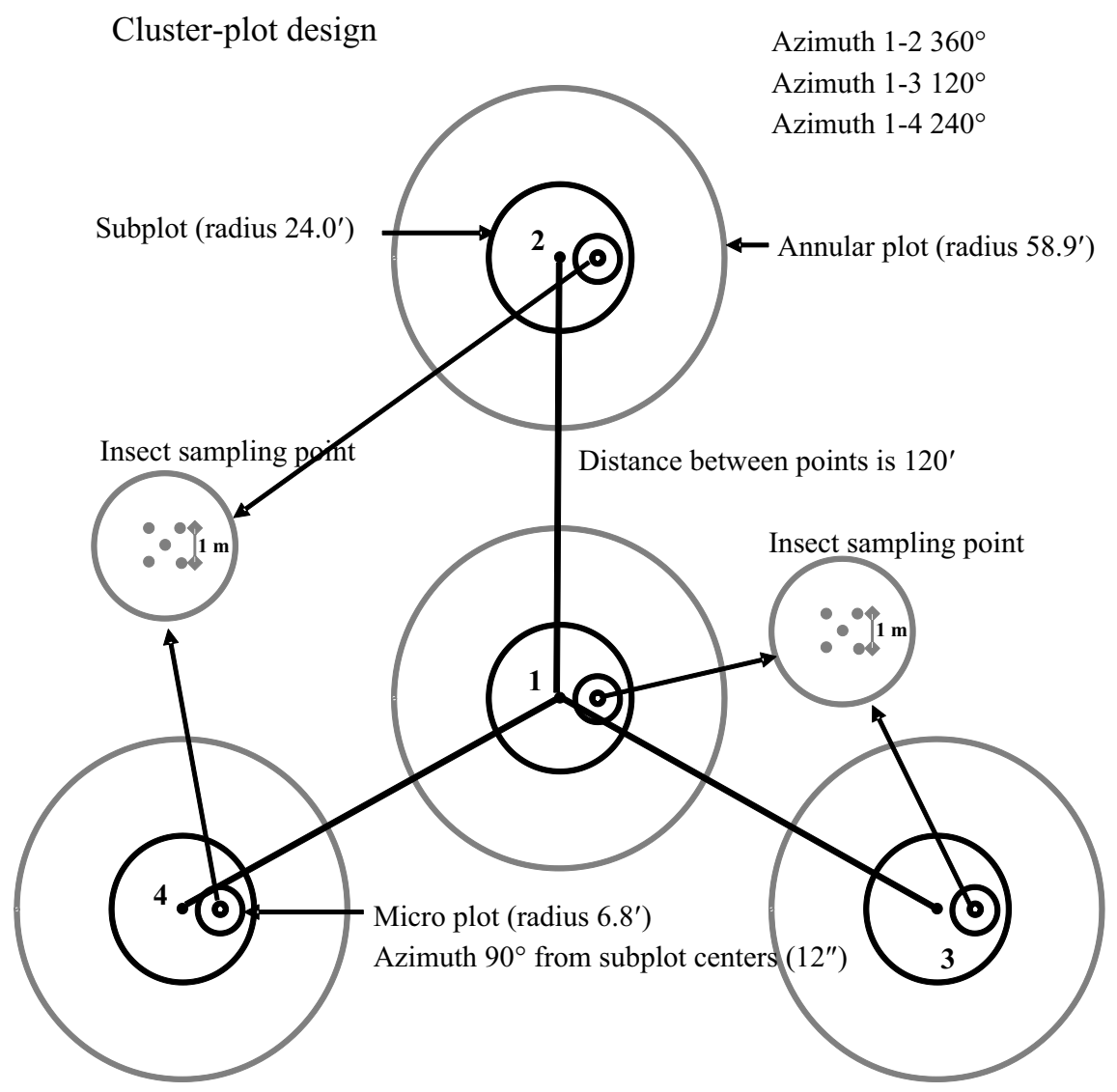

Figure 1 Cluster plot-design for ground ants sampling before clear cutting and after clear cutting. 

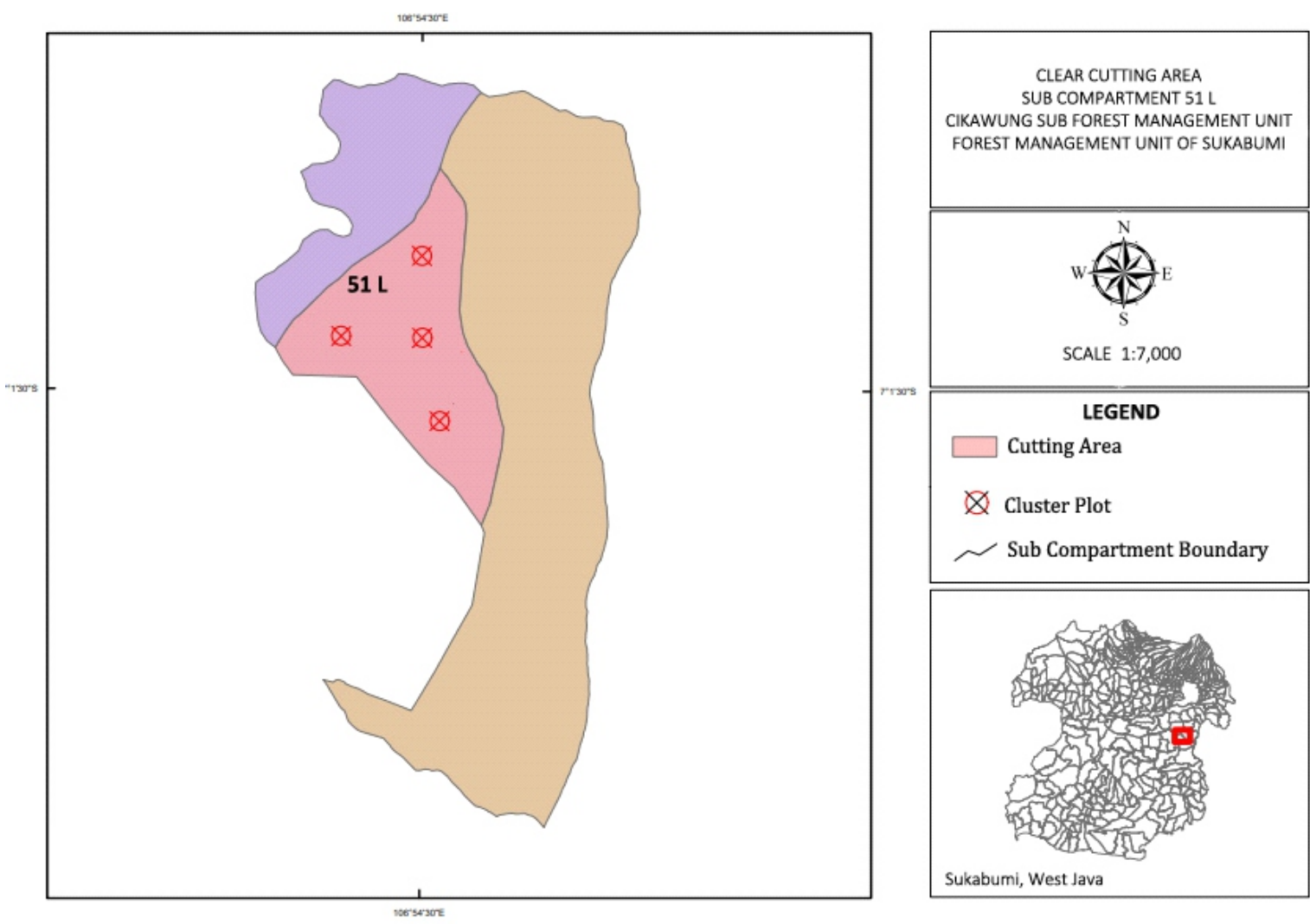

Figure 2 Layout of the cluster plot in the study area.

Measurement of environmental factors was carried out in the insect sampling point. Environmental factors measured were canopy cover, air temperature, and relative humidity. Measurement of air temperature and relative humidity was done using a digital thermohygrometer in the morning (08.00-9.00 pm), afternoon (12.00-13.00 am), and evening (15.00-16.00 am). Canopy cover measurements were carried out using a spiracle densiometer at the four wind directions (north, east, south, and west) from the center of the micro plot.

The ground ant community index, such as abundance, morphospecies composition, Shannon-Wiener diversity index $(\mathrm{H})$, Margalef richness index (DMg), Jaccard similarity index (JI), and evenness index (E) were calculated and compared before and after clear cutting. Mann-Whitney test was used to analyze differences in abundance, morphospecies composition, diversity index, richness index, and evenness index of ground ant before and after clear cutting because all variables do not meet the assumptions of normal distribution.

\section{Results and Discussion}

The total number of ground ants before clear cutting was 1,234 individuals, representing 8 subfamilies and 26 morphospecies. After clear cutting, the number of individual ground ants was 1011 individuals belonging to 4 subfamilies and 21 morphospecies. The highest abundant morphospecies before clear cutting was Pheidole sp. 2 (388 individuals).
The two other dominant morphospecies before cutting was Pheidole sp. 1 (209 individuals) and Myrmicaria sp. (162 individuals). The most abundant morphospecies before clear cutting (Pheidole sp. 2) was slightly decreased after clear cutting, but the second and third most abundance morphospecies before clear cutting, Pheidole sp. 1 and Myrmicaria sp., were slightly increased after clear cutting (Table 1). Pheidole sp. 1 was the highest morphospecies (452 individuals) after clear cutting, followed by Myrmicaria sp. (188 individuals) and Pheidole sp. 2 (52 individuals).

Clear cutting of pine plantation forest decreased the abundance of ground ants. The average abundance of ground ants before clear cutting was significantly different from that of after clear cutting $(p<0.05)$. The average morphospecies composition of ground ants before clear cutting was greater than after clear cutting. The morphospecies composition of ground ants before clear cutting was significantly different with that of after clear cutting $(p<0.05)$ (Table 2$)$.

The number of subfamily ground ants before cutting was higher than after clear cutting. The three biggest subfamilies found in the study site before and after clear cutting were Myrmicinae, Ponerinae, and Formicinae (Figure 3). Five other subfamilies, such as Dolichoderinae, Pseudomyrmicinae, Dorylinae, Proceratiinae, and Amblyoponinae, only had an abundance of less than $1 \%$. Myrmicinae was the subfamily with the highest abundance 
Table 1 Abundance of ground ants before clear cutting and after clear cutting

\begin{tabular}{|c|c|c|c|c|c|c|}
\hline \multirow{2}{*}{ No. } & \multirow{2}{*}{ Subfamily } & \multirow{2}{*}{ Morphospecies } & \multicolumn{2}{|c|}{ Before clear cutting } & \multicolumn{2}{|c|}{ After clear cutting } \\
\hline & & & (individual) & $\%$ & (individual) & $\%$ \\
\hline 1 & Amblyoponinae & Amblyopone sp. & 1 & 0.08 & 0 & 0.00 \\
\hline 2 & Dolichoderinae & Tapinoma sp. & 7 & 0.57 & 0 & 0.00 \\
\hline 3 & Dorylinae & Aenictus sp. & 5 & 0.41 & 0 & 0.00 \\
\hline 4 & Formicinae & Nylanderia $\mathrm{sp}$. & 55 & 4.46 & 15 & 1.48 \\
\hline 5 & Formicinae & Polyrhachis sp. & 2 & 0.16 & 0 & 0.00 \\
\hline 6 & Formicinae & Prenolepis sp. & 6 & 0.49 & 28 & 2.77 \\
\hline 7 & Myrmicinae & Aphaenogaster sp. & 47 & 3.81 & 29 & 2.87 \\
\hline 8 & Myrmicinae & Crematogaster sp. & 22 & 1.78 & 16 & 1.58 \\
\hline 9 & Myrmicinae & Myrmicaria sp. & 162 & 13.13 & 188 & 18.6 \\
\hline 10 & Myrmicinae & Pheidole sp. 3 & 4 & 0.32 & 17 & 1.68 \\
\hline 11 & Myrmicinae & Pheidole sp. 4 & 20 & 1.62 & 49 & 4.85 \\
\hline 12 & Myrmicinae & Pheidole sp. 1 & 209 & 16.94 & 452 & 44.71 \\
\hline 13 & Myrmicinae & Pheidole sp. 2 & 388 & 31.44 & 52 & 5.14 \\
\hline 14 & Myrmicinae & Strumigenys sp. & 18 & 1.46 & 0 & 0.00 \\
\hline 15 & Ponerinae & Anochetus sp. & 21 & 1.70 & 29 & 2.87 \\
\hline 16 & Ponerinae & Brachyponera sp. & 13 & 1.05 & 18 & 1.78 \\
\hline 17 & Ponerinae & Diacamma sp. & 3 & 0.24 & 5 & 0.49 \\
\hline 18 & Ponerinae & Ectomomyrmex sp. & 31 & 2.51 & 40 & 3.96 \\
\hline 19 & Ponerinae & Leptogenys sp. 1 & 19 & 1.54 & 4 & 0.40 \\
\hline 20 & Ponerinae & Leptogenys sp. 3 & 10 & 0.81 & 13 & 1.29 \\
\hline 21 & Ponerinae & Leptogenys sp. 4 & 36 & 2.92 & 0 & 0.00 \\
\hline 22 & Ponerinae & Leptogenys sp. 5 & 12 & 0.97 & 8 & 0.79 \\
\hline 23 & Ponerinae & Leptogenys sp. 6 & 60 & 4.86 & 14 & 1.38 \\
\hline 24 & Ponerinae & Odontoponera sp. & 75 & 6.08 & 24 & 2.37 \\
\hline 25 & Proceratiinae & Proceratium sp. & 2 & 0.16 & 10 & 0.99 \\
\hline 26 & Pseudomyrmicinae & Tetraponera sp. & 6 & 0.49 & 0 & 0.00 \\
\hline \multicolumn{3}{|c|}{ Total } & 1,234 & 100 & 1,011 & 100 \\
\hline
\end{tabular}

Table 2 Community indices, environmental data (mean, standard error, and range), and Mann-Whitney test for the difference between treatment

\begin{tabular}{|c|c|c|c|c|}
\hline Variable & $\begin{array}{l}\text { Before clear } \\
\text { cutting }\end{array}$ & $\begin{array}{l}\text { After clear } \\
\text { cutting }\end{array}$ & $\begin{array}{c}\text { Mann-Whitney } \\
\text { value; } p \text {-value }\end{array}$ & Difference \\
\hline Abundance $\left(\operatorname{trap}^{-1}\right)$ & $\begin{array}{l}9.00 \pm 2.71 \\
0.00-200.00\end{array}$ & $\begin{array}{l}6.00 \pm 3.21 ; \\
0.00-236.00\end{array}$ & $\mathrm{~W}=7143.5 ; 0.02$ & * \\
\hline $\begin{array}{l}\text { Morphospecies } \\
\text { composition }\left(\operatorname{trap}^{-1}\right)\end{array}$ & $\begin{array}{c}3.50 \pm 0.18 \\
0.00-7.00\end{array}$ & $\begin{array}{c}2.00 \pm 0.17 \\
0.00-6.00\end{array}$ & $\mathrm{~W}=7549.5 ; 0.00$ & $*$ \\
\hline Diversity index & $\begin{array}{c}0.95 \pm 0.06 \\
0.00-1.95\end{array}$ & $\begin{array}{c}0.63 \pm 0.06 \\
0.00-1.67\end{array}$ & $\mathrm{~W}=7405.0 ; 0.00$ & $*$ \\
\hline Richness index & $\begin{array}{c}1.21 \pm 0.07 \\
0.0-3.1\end{array}$ & $\begin{array}{c}0.72 \pm 0.07 \\
0.0-2.1\end{array}$ & $\mathrm{~W}=7427.5 ; 0.00$ & $*$ \\
\hline Evenness index & $\begin{array}{c}0.82 \pm 0.04 \\
0.00-1.00\end{array}$ & $\begin{array}{c}0.77 \pm 0.04 \\
0.00-1.00\end{array}$ & $\mathrm{~W}=6836.0 ; 0.18$ & ns \\
\hline Canopy cover $(\%)$ & $\begin{array}{c}49.46 \pm 2.18 \\
6.88-74.31\end{array}$ & $\begin{array}{c}0.0 \pm 0.0 \\
0.0-0.0\end{array}$ & $\mathrm{~W}=9027.5 ; 0.00$ & * \\
\hline Air temperature $\left({ }^{\circ} \mathrm{C}\right)$ & $\begin{array}{l}24.40 \pm 0.42 \\
20.10-31.70\end{array}$ & $\begin{array}{l}25.7 \pm 0.49 \\
23.20-33.40\end{array}$ & $\mathrm{~W}=6218.5 ; 0.09$ & ns \\
\hline Humidity (\%) & $\begin{array}{c}80.30 \pm 0.90 \\
63.00-93.00\end{array}$ & $\begin{array}{c}64.00 \pm 0.86 \\
51.70-75.00\end{array}$ & $\mathrm{~W}=7373.5 ; 0.00$ & $*$ \\
\hline
\end{tabular}

Note: $*$ = significant; $\mathrm{ns}=$ non-significant 


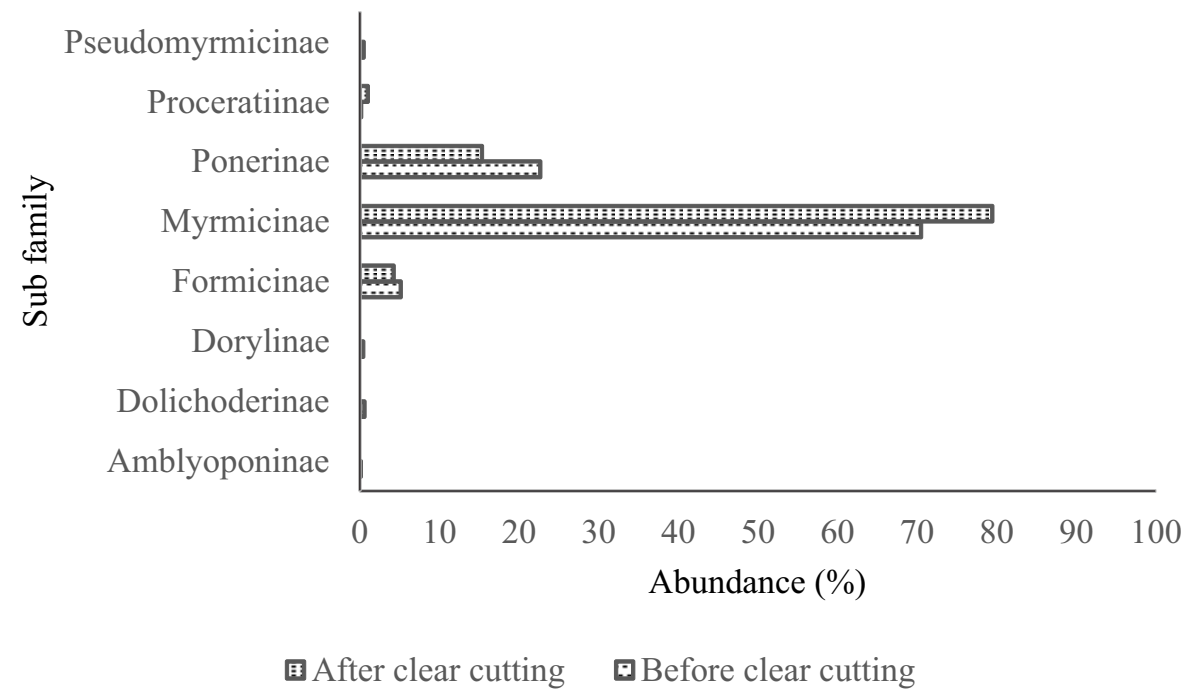

Figure 3 Individual number of the subfamily of ground ants before clear cutting and after clear cutting.

( $70.50 \%$ of the individuals before clear cutting; $79.43 \%$ after clear cutting), followed by Ponerinae $(22.69 \%$ of the individuals before clear cutting; $15.33 \%$ after clear cutting), and Formicinae $5.11 \%$ of the individuals before clear cutting; $4.25 \%$ after clear cutting). Four subfamilies were not found after clear cutting, i.e. Dolichoderinae, Pseudomyrmicinae, Dorylinae, and Amblyoponinae.

The average diversity index of ground ants before clear cutting was higher than after clear cutting. The average diversity index of ground ants before cutting was 0.90 , whereas after clear cutting was 0.63 . The results of the study indicated that the diversity index of ground ants before clear cutting and after clear cutting was different. The result of the study showed that the average richness index of ground ant before clear cutting was 1.15 , while after clear cutting was 0.79 . The Mann-Whitney test showed that the average richness index of the ground ants before clear cutting was significantly different from that of after clear cutting. The average evenness index of the ground after clear cutting decreased by $15 \%$. The average evenness index of ground ants before clear cutting did not differ with after clear cutting (Table 2). The average similarity index of ground ants before clear cutting and after clear-cutting was classified as low $(56 \%)$. The highest similarity index was $80 \%$, and the smallest was $50 \%$.

The abundance, morphospecies composition, diversity index, richness index, and evenness index of ground ants after clear cutting was lower than before clear cutting. The study showed that the abundance, morphospecies composition, diversity index, and richness index before clear cutting are significantly different from that of after clear cutting. However, it was found that the average evenness index of the ground ants before clear cutting and after clear cutting was similar. The total abundance of ground ants was $18 \%$ lower after clear cutting. The decrease in abundance, morphospecies composition, diversity index, richness index, and evenness index of ground ant after clear cutting was suspected due to reducing the availability of favorable microhabitat for ground ants, especially for close habitats morphospecies. The results of this study were consistent with previous studies. Woodcock et al. (2013) reported that ant abundance changes following logging. The ant abundance in the logged forest was lower than in the unlogged forest. Besides, the highly disturbed forest (damaged ecosystem) had lower species diversity than the undisturbed forest (Andersen et al. 2002; Graham et al. 2004; King et al. 1998). The study showed that the majority of ground ants ( $73 \%$ of total morphospecies) still survived after clear cutting and the remaining $(27 \%$ of total morphospecies) were not found after clear cutting. The results of this study were consistent with previous studies in temperate forests. Tausan et al. (2017) reported that many species of forest ants still survive after clear cutting. Meanwhile, the morphospecies composition, diversity index, and richness index of ground ants before clear cutting was significantly different from that of after clear cutting.

The study showed that clear cutting did not provide vegetation cover and created an area that was directly exposed to sunlight. There were not yet any land treatments (land preparation, slash burning) after clear cutting, except the collection of clear cutting residues (twigs, small branches) by local people. Besides, clear cutting reduced coarse woody debris and rotten wood, which become the main food source for some morphospecies of ground ants. The difference in the morphospecies composition before and after clear cutting may be caused by a significant difference in the diversity index and richness index of ground ant species before and after clear cutting. The study also showed that although some forest ground ants can survive after clear cutting, the total abundance of ground ants after clear cutting was less than those before clear cutting. It indicated that the majority of ground ants may be affected by clear cutting. Stenbacka et al. (2010) reported that the composition of some insect taxa changes with the decreasing trees, deadwood, and forest canopy strata.

There were four functional roles of ground ants in the 
study site, which were found both before clear cutting and after clear cutting, i.e. generalist, predator, forager, and unknown functional role (UFR). Generalist ground ant was the most abundant functional groups in the study site (56.08\% of the individuals before clear cutting; $60.83 \%$ of the individuals after clear cutting), and then followed by a predator $(38.74 \%$ of the individuals before clear cutting; $36.70 \%$ of the individuals after clear cutting), forager $(5.02 \%$ of the individuals before clear cutting; $1.48 \%$ of the individuals after clear cutting), and UFR $(0.16 \%$ of the individuals before clear cutting; $0.99 \%$ of the individuals after clear cutting). The functional rank of the ground ants did not change after clear cutting. Clear cutting caused a shift in the abundance of the functional role of the ground ants. The abundance of predator and forager decreased after clear cutting, while the generalist groups increased after clear cutting (Figure 4). The two most dominant morphospecies among the generalist group before clear cutting was Pheidole sp. 2 (31.44\% of the total individuals) and Pheidole sp. 1 (27.45\% of the total individuals). The most dominant morphospecies among the predator group before clear cutting was Myrmicaria sp (13.13\% of the total individuals). After clear cutting, the most abundant generalist group was Pheidole sp. 1 (44.71\% of the total individuals). The most abundant predator group after clear cutting was the same as before clear cutting, i.e Myrmicaria sp. (18.60\% of the total individuals).

The study showed that seven morphospecies (Tapinoma sp., Tetraponera sp., Aenictus sp., Strumigenys sp., Leptogenys sp. 4, Polyrhachis sp., and Amblyopone sp.) were not found after clear cutting. These seven morphospecies may be typical morphospecies of forest habitat. Three morphospecies, i.e. Pheidole sp. 1, Pheidole sp. 2, dan Myrmicaria sp., were the dominant morphospecies, both before clear cutting and after clear cutting. These three morphospecies originated from the subfamily of Myrmicinae. Besides, these three morphospecies may have a wide spectrum of habitat preferences, from undisturbed habitats to habitats with severe disturbance and open habitat. The results of this study were mainly in line with previous studies conducted in the temperate region. The most common species found in disturbed forests without vegetation cover were the generalist group of Myrmicinae and the opportunist (Tausan et al., 2017; King et al., 1998). The study indicated that clear cutting caused a shift in the functional role of ground ants. The group of generalists, predators, and foragers ants after clear cutting decreased by $11.13 \%, 22.38 \%$, and $75.81 \%$ respectively, while the unknown functional group increased by $400 \%$ after clear cutting. The previous study in the tropical anthropogenic landscape in Venezuela found that the number of predators in the logged forest was lower than those in the un-logged forest, while the number of generalist groups in the logged forest was higher than those in the un-logged forest (GarciaMartinez et al., 2015).

The study indicated that clear cutting altered the habitat of the ground ant. Clear cutting completely removed canopy cover, increased air temperature, and decreased air humidity. The average air temperature increased from $24.76 \mathrm{C}$ to 27.14 C, while humidity decreased from $79.91 \%$ to $64.98 \%$ (Table 2). The study showed that the species richness of ground ants in the open habitat was lower compared to close habitat with canopy covers (before clear cutting). Khaliq et al. (2014) reported that canopy cover, air humidity, and air temperature were the determinant environmental factors for the ground ant habitat. Change in canopy cover, air humidity, and air temperature will alter the diversity of many morphospecies of ground ants. Garcia-Tejero et al. (2018) reported that forest canopy cover affects the diversity of many arthropod groups, including ants.

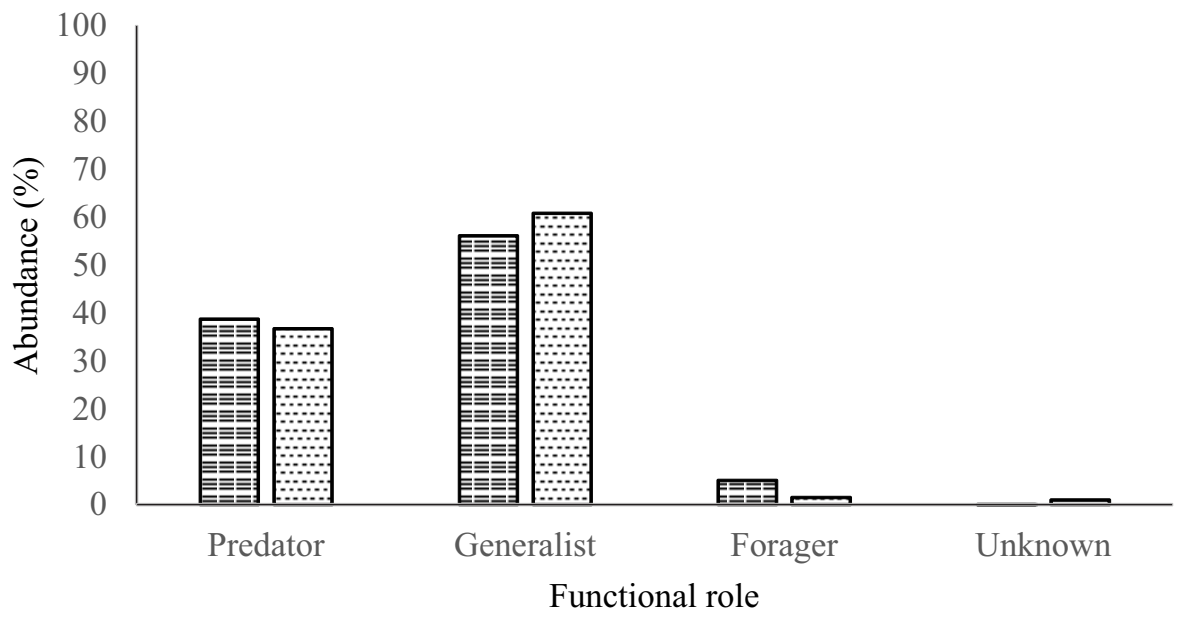

目Before clear cutting $\mathbf{0}$ After clear cutting

Figure 4 Abundance of ground ants before clear cutting and after clear cutting based on functional role. 


\section{Conclusion}

This study collected essential information about the relationship between clear cutting and diversity of ground ant community in the plantation forest. Although some morphospecies of ground ants seem to be resistant to clear cutting, the abundance, morphospecies composition, diversity index, and species richness index of ground ants were significantly changed after clear cutting. This study compared the diversity of ground ants before clear cutting and after clear cutting in the pine plantations forest in the short term (six days after clear cutting). The study provided a preliminary finding of the impacts of a forest management practice on the specific order of insects. The impacts may vary in direction and magnitude depending on the logging systems, logging intensity, insect family, and time after logging. Based on the results of this study, it would be useful to develop a study on the long-term impacts of forest management practices on the insects' community in Indonesian plantation forests.

\section{Acknowledgment}

The authors would like to thank the Forest Management Unit of Sukabumi for technical support, facilities, and accommodation.

\section{References}

Acuna, M. P., \& Estades, C. F. (2011). Plantation clearcut size and the presistence of early-succesional wildlife populations. Biological Conservation, 144, 1577-1584. https://doi.org/10.1016/j.biocon.2011.02.003

[AIFCH] Association of Indonesia Forest Concession Holders. (2019). Road map of production forest development year 2019-2045. Jakarta.

Andersen, A. N. (2000). Global ecology of rainforest ants: Functional groups in relation to environmental stress and disturbance. In D. Agosti, J. D. Majer, L. E. Alonso, \& T. R. Schultz (Eds.), Ants: Standard methods for measuring and monitoring biodiversity (pp. 18). Washington DC: Smithsonian Institution Press.

Andersen, A. N., Hoffmann, B. D., Müller, W. J., \& Griffiths, A. D. (2002). Using ants as bioindicators in land management: Simplifying assessment of ant community responses. Journal of Applied Ecology, 39(1), 8-17. https://www.jstor.org/stable/827215

Andersson, J., Hjältén, J., \& Dynesius, M. (2012). Long-term effects of stump harvesting and landscape composition on beetle assemblages in the hemiboreal forest of Sweden. Forest Ecology and Management, 271, 75-80. https://doi.org/10.1016/j.foreco.2012.01.030

Andini, S., Budiaman, A., \& Muhdin. (2017). Development of line intersects method for logging residue assessment of teak. Jurnal Manajemen Hutan Tropika, 23(2), 51-60. https://doi.org/10.7226/jtfm.23.2.51

Bolton, B. (1994). Identification guide to the ant genera of the world. Cambridge: Harvard University Press.
Borror, D. J., Triplehorm, C. A., \& Jhonson, N. F. (1996). An introduction to the study of insects. New York: Hartcourt Brace College Publisher.

Brockerhoff, E. G., Jactel, H., Oarrota, J. A., Ferraz, S. F. B. (2013). Role of eucalypt and other planted forests in biodiversity conservation and the provision of biodiversity-related ecosystem services. Forest Ecology and Management, 301, 43-50. https://doi.org/10.1016/ j.foreco.2012.09.018

Budiaman, A., Muhtariana, D., \& Irmawati, N. Y. (2014). Kayu sisa penjarangan dan tebang habis hutan tanaman jati. Jurnal Hutan Tropis, 2(1), 9-15. https://doi.org/ 10.20527/jht.v2i1.1707

[CBS] Central Bureau of Statistic. (2013). Statistics of Indonesia 2018. Jakarta.

Česonienė, L., Daubaras, R., Kaškonas, P., Kaškonienė, V., Maruška, A. S., Tiso, N., \& Zych, M. (2018). Initial impact of clear-cut logging on dynamics of understory vascular plants and pollinators in Scots pine-dominated forests in Lithuania. Turkish Journal of Agriculture and Forestry, 42, 433-443. https://doi.org/10.3906/tar-180471

Eyre, T. J., Ferguson, D. J., Kennedy, M., Rowland, J., \& Maron, M. (2015). Long term thining and logging in Australian cypress pine forest: change in habitat attributes and response of fauna. Biological Conservation, 186, 83-96. https://doi.org/10.1016/ j.biocon.2015.03.009

Garcia-Tejero, S., Spence, J. R., O'Halloran, J., Bourassa, S., \& Oxbrough, A. (2018). Natural succession and clearcutting as drivers of environmental heterogeneity and beta diversity in North American boreal forests. PLOS ONE, 13, e0206931. https://doi.org/10.1371/ journal.pone.02069316x

Garcia-Martinez, M. A., Martinez-Tlapa, D. L., PerezToledo, G. R., Quiroz-Robledo, L. N., Castano-Meneses, G., Laborde, J., \& Valenzuela-Gonzalez, J. E. (2015). Taxonomic, species and functional group diversity of ants in a tropical anthropogenic landscape. Tropical Conservation Science, 8, 1017-1032. https://doi.org/ 10.1177\%2F194008291500800412

Graham, J. H., Hughie, H. H., Jones, S., Wrinn, K., Krzysik, A. J., Duda, J, ..., \& Balbach, H. (2004). Habitat disturbance and the diversity and abundance of ants (Formicidae) in the Southeastern Fall-Line Sandhills. Journal of Insects Science, 4, 30. https://doi.org/ $10.1093 / \mathrm{jis} / 4.1 .30$

Haneda, N. F., \& Marfuah, N. T. (2013). Diversity of soil arthropods in teak forest plantation at Cepu, Blora, Central Java. Jurnal Manajemen Hutan Tropika, 19, 169-177. https://doi.org/10.7226/jtfm.19.3.169

Haneda, N. F., \& Yuniar, N. (2020). Peranan semut di 
ekosistem transformasi hutan hujan tropis dataran rendah. Jurnal Ilmu Kehutanan, 14, 16-27. https://doi.org/10.22146/jik/57459

Johansson, T., \& Gibb, H. (2012). Forestry alters foraging efficiency and crop contents of aphid-tending red wood ants. Formica aqui lonia. PLOS ONE, 7, e32817. https://doi.org/10.1371/journal.pone.0032817

Johansson, T., Hjältén, J., Olsson, J., Dynesius, M., \& Roberge, J-M. (2016). Long-term effects of clear cutting on epigaic beetle assemblages in boreal forests. Forest Ecology and Management, 359, 65-73. https://doi.org/ 10.1016/j.foreco.2015.09.041

Jokela, J., Siitonen, J., \& Koivula, M. (2019). Short-term effects of selection, gap, patch and clear cutting on the beetle fauna in boreal spruce dominated forest. Forest Ecology and Management, 446, 29-37. https://doi.org/ 10.1016/j/foreco.2019.05.027

Khaliq, A., Javed, M., Sohail, M., \& Sagheer, M. (2014). Environmental effects on insects and their population dynamics. Journal of Entomology and Zoology Studies, $2,1-7$.

King, J. R., Andersen, A. N., \& Cutter, A. D. (1998). Ants as bioindicators of habitat disturbance: Validation of the functional group model for Australia's humid tropics. Biodiversity \& Conservation 7, 1627-1638.

Lessard, J-P. (2019). Ant community response to disturbance: a global synthesis. Journal of Animal Ecology, 88, 346-349. https://doi.org/10.1111/13652656.12958

Matangaran, J. R., \& Suwarna, U. (2012). Soil compaction caused by two types of forwarder in forest harvesting. Journal of Life Sciences and Physic, 14, 115-124.

[MEF] Ministry of Environment and Forestry. (2019). Statistics of Directorate General of Sustainable Production Forest Management. Jakarta.

Paillet, Y., Berges, L., Hjalten, J., Odor, P., Avon, C., Benhardt-Romermann, M., ..., \& Virtanen, R. (2010). Biodiversity differences between managed and unmanaged forests: Meta-analysis of species richness in Europe. Conservation Biology, 24, 101-112. http://doi.org/10.1111/j.1523-1739.2009.01359.x

Perum Perhutani. (2006). Statistics of Perum Perhutani 2001-2005. Jakarta: Perum Perhutani.

Ribas, C. R., Campos, R. B. F., Schmidt, F. A., \& Solar, R. R. (2012). Ants as indicators in Brazil: A review with suggestions to improve the use of ants in environmental monitoring programs. Psyche: A Journal of Entomology, 2012, 636749. https://doi.org/10.1155/2012/636749

Stenbacka, F., Hjalten, J., Hilszczanski, J., \& Dynesius, M. (2010). Saproxylic and non-saproxylic beetle assemblages in boreal spruce forests of different age and forestry intensity. Ecology Application, 20, 2310-2321. https://doi.org/10.1890/09-0815.1

Supangat, A. B., Sudira, P., Supriyo, H., \& Poedjiraharjoe, E. (2016). Pengaruh penebangan hutan tanaman Eucalyptus pellita F.Muell terhadap peningkatan aliran sungai dan sedimen. Jurnal Penelitian Hutan Tanaman, 13(2), 113-122.

Tausan, I., Dauber, J., Trica, M. R., \& Marko, B. (2017). Succession in ant communities (Hymenoptera: Formicidae) in deciduous forest clear-cuts - an Eastern European case study. European Journal of Entomology, 114,92-100. https://doi.org/10.14411/eje.2017.013

Tiede, Y., Schlautmann, J., Donoso, D. A., Walkis, C.I.B., Bendix, J., Brandl, R., \& Farwig, N. (2017). Ants as indicators of environmental change and ecosystem process. Ecological Indicators, 83, 527-537. https://doi.org/10.1016/j.ecolind.2017.01.029

Warman, R. (2014). Global wood production from natural forest has peaked. Biodiversity and Conservation, 23, 1063-1078. https://doi.org/10.1007/s10531-014-0633-6

Wibowo, C., \& Slamet, S. A. (2017). Keanekaragaman makrofauna tanah pada berbagai tipe tegakan di areal bekas tambang silika di Holcim Educational Forest, Sukabumi, Jawa Barat. Jurnal Silvikultur Tropika, 8(1), 26-34.

Widhiono, I., Pandhani, R. D., Darsono, Riwidiharso, E., Santoso, S., \& Prayoga, L. (2017). Ant (Hymenoptera:Formicidae) diversity as bioindicator of agroecosystem health in northern slope of Mount Slamet, Central Java, Indonesia. Biodiversitas, 18, 1475-1480. https://doi.org/10.13057/biodiv/d180424

Woodcock, P., Edward, D. P., Newton, R. J., Khen, C. V., Bottreli, S. H., \& Hamer, K. C. (2013). Impacts of intensive logging on the trophic organisation of ant communities in a biodiversity hotspot. PLOS ONE, 8, e60756. https://doi.org/10.137/journal.pone.0060756

Żmihorski, M. (2010). Distribution of red wood ants (Hymenoptera: Formicidae) in the clear-cut areas of a managed forest in Western Poland. Journal of Forestry Research, 15, 145-148. https://doi.org/10.1007/s10310009-0161-5 